\title{
Revitalization of Mathematical Education Through Applying Productive Pedagogies Framework
}

\author{
Suhendra \\ Department of Mathematics Education \\ Indonesia University of Education \\ Bandung, Indonesia \\ suhendra@upi.edu
}

\author{
Ela Nurlaela \\ Department of Mathematics Education \\ Indonesia University of Education \\ Bandung, Indonesia \\ suhendra@upi.edu
}

\begin{abstract}
Mathematics is often perceived as a difficult subject with many students failing to understand why they need to learn the subject. The teaching and learning of mathematics mostly has relied on the transfer of information from the teachers to their students. Therefore, teaching and learning of mathematics should be reformed in order to be more meaningful for students.

This study examined the usefulness of implementing Connectedness dimension of the Productive Pedagogies framework, as a means of improving the quality of teaching and learning of mathematics. In all cases, using the elements of Connectedness dimension of the Productive Pedagogies framework helped teachers to make mathematics more relevant to students, by including students' prior knowledge, connecting the lessons with other topics, integrating other subjects into the lessons and providing sufficient relevant illustrations. As one of the impacts, the students became more enthusiastic to attend their mathematics classes and displayed more on-task and engaged behaviours during the learning activities. The success of the participant-teachers, by applying the Connectedness dimension of the Productive Pedagogies framework has demonstrated its overall usefulness and provided lessons from which further use of the framework might build upon.
\end{abstract}

Keywords: Productive Pedagogies framework, Connectedness dimension

\section{INTRODUCTION}

There is broad consensus among policy makers, curriculum planners, school administrators and business and industry leaders that mathematics is an important element of the school curriculum. The importance of mathematics is implicitly accepted by governments around the world through the emphasis placed on monitoring school improvement in terms of mathematics outcomes [1]. Further, Mathematical proficiency has been identified as one of the key competencies necessary for personal fulfilment, active citizenship, social inclusion and employability in the knowledge society [2]. Mathematics competence enhances students' abilities to communicate and negotiate meanings [3].

Despite the importance of mathematics to the lives of students, mathematics teaching and learning continues to be an area of concern around the world, Indonesia being no exception. It is well documented that many students struggle with mathematics and, as a result, become disaffected. Much research has suggested that mathematics education continues to be fundamentally disconnected from learners' lives and irrelevant to their needs [4]. According to [2], mathematics, both at school and within the wider community, is often perceived as difficult and abstract, involving a significant number of processes and formulae that appear disconnected with each other. It is important, therefore, that we understand what effective mathematics teaching looks like [5]. To this end, past research in the field of mathematics education has sought to distil important aspects of teaching and learning, including the specific ways in which quality teaching operates, the degree to which teaching drives learning, and how effectiveness evolves as teachers' progress [6].

In Indonesia, the teaching and learning of mathematics was largely teacher-oriented, with a focus on drill and was, for the most part, mechanistic, with teachers dictating formulas and procedures to their students [7]. These pedagogical approaches tend to lead to classrooms in which students play a passive role and are viewed, by the teacher, as objects of teaching [8][9]. In the majority of mathematics classes, in Indonesia, mathematics teaching relies on the transfer of information from the teacher to his or her students. There is, however, a growing awareness 
of the need to improve mathematics teaching in schools [10] and, according to [11], one of the biggest concerns raised by mathematics teachers in Indonesia is the need to make mathematics lessons more relevant to their students' needs.

\section{THEORIES OF LEARNING}

Given that, predominantly, the view of learning in Indonesia is one of transmission of knowledge, in which the teacher is the transmitter and students the receiver, the implementation of the Productive Pedagogies framework required teachers to reconsider how students learn and to change their teaching to reflect this. The research, investigated the effectiveness of implementing the Productive Pedagogies framework, which was one of its dimensions - Connectedness dimension - required teachers to reconsider deeply entrenched notions of teaching and learning. Therefore, this section discusses some of the theories of learning upon which the Productive Pedagogies framework was based.

\section{A. Knowledge Acquisition}

A prevailing view of the human mind is that, essentially, it is empty of knowledge at birth and, throughout a person's lifetime, new knowledge is gradually acquired and utilised. This approach involves a set of initial premises, which form the basis for the development of a proposition for how knowledge is created, retained, distributed and used [12]. Knowledge acquisition typically begins with the process of receiving or acquiring new knowledge. A review of literature indicates that there are two elements of knowledge acquisition: one is related to the theories of knowledge acquisition (conceptualizing how knowledge is acquired and interpreted in the mind of learner); the other is a psychological perspective of knowledge acquisition (concerned with a person's ability to acquire knowledge and how it is internally represented) [13].

Some approaches to knowledge acquisition have been built upon the idea that people have a predisposition toward knowledge or are born with certain values that already exist. This is usually done through visual or aural signals that a person receives through his or her senses. [12] purports that information or knowledge is acquired through the sensors and is processed in the brain by using prior knowledge. During the processing of information, new knowledge can be acquired or created for future use.

Once information is received, knowledge acquisition continues through encoding and understanding that information. This encoding process allows a person to use information to build a cognitive model, called a schema [14]. That is, a schema for 'something' incorporates the received information to build an overall sense of what constitutes that 'something.' When a person sees another thing, for example, he or she processes the new information or knowledge and, when it does not fit the schema of 'something', he or she then creates a new model that accommodates that new knowledge. According to [14], this knowledge acquisition continues with the ability to effectively recall and alter stored information. For instance, when someone sees 'something' again, he or she is able to recognize it as 'something' by recalling the schema for the 'something' and seeing that it fits into that model. This can create cognitive dissonance when someone encounters an object that exists within a certain schema, but which does not match certain aspects of that model.

\section{B. Constructivism}

The dominant view of learning in Indonesia has, to date, been one involving a knowledge transfer model in which knowledge is transmitted from teachers to students [15][16]. However, if, as discussed above, knowledge acquisition is the process of acquiring, processing, understanding and recalling information, then this implies that learning is not simply a transfer process. This theoretical shift (to the notion that learners build their own knowledge) although not widely accepted or used, has started to take place in Indonesia [8][10][16]. Given that the Productive Pedagogies framework, used in the present study, draws on the theory of constructivism in its design, this section provides a brief overview of constructivism.

As a theory of learning, constructivism asserts that people learn by actively constructing meaning rather than by receiving information [17]. According to [18], learning requires the building of conceptual structures through learner reflection and abstraction; both of which are active processes involving the interaction between the learners' existing conceptual frameworks and the new knowledge and experience. Constructivism is not a teaching method but, rather, provides a framework for designing the teaching and learning processes in a real, complex, ever-changing and unpredictable classroom in which multiple factors -individual, social and cultural - are interacting [19].

Given that learners construct knowledge based on their personal experiences and past knowledge, it is likely that the nature of what is constructed may be different for different students, even though they are in the same classroom [20]. In other words, learning is an individual activity and, therefore, no two students will leave a class with exactly the same understanding [21]. As such, it is important that teachers help students to 
examine their understanding of concepts. According to [22], "the nature of an individual's personally constructed meaning is strongly influenced by his or her existing ideas and beliefs". That is, students' constructions of knowledge are influenced by their own views as well as by the nature of the learning and teaching process. It is important, therefore, that teachers are aware of their students' prior knowledge and experiences and consider these as a starting point when teaching, making use of them to develop students' new understanding within the lessons that they are delivering.

An important principle associated with constructivism is the notion that all knowledge must be linked to and is built upon previous knowledge. [23] describe prior knowledge as "the knowledge, skills, or ability that students bring to the learning process". Past research has indicated that prior knowledge plays a major role in student learning and the implications that this has on mathematics teaching important [24]. The importance of the teachers' recognition and value for prior knowledge has been highlighted in past research [25]. These theories suggest the need for teachers to recognize that students construct their own meaning and that prior learning can be used to facilitate student understanding.

The Productive Pedagogies, as a teaching framework, considers knowledge acquisition as the process by which new knowledge is received or acquired. The framework espouses that the success of knowledge acquisition is related to the process of acquiring, processing, understanding and recalling information, all of which are related to constructing knowledge. Therefore, consideration of knowledge acquisition as well as the construction of knowledge was viewed as important in developing effective teaching.

\section{Effective Mathematics Teaching}

Given that the research sought to examine the impact of implementing the Productive Pedagogies framework it was considered important to examine literature related to what constitutes effective mathematics teaching and, in particular, the role of the teacher in optimizing students' learning outcomes.

Mathematics is the most universal of all curriculum subjects, and mathematical understanding influences decision making in almost all of our daily life. Competence in mathematics has been identified as one of the key competences for personal fulfilment, active citizenship, social inclusion and employability in the knowledge society of the 21st century [2].
Even though competence in mathematics is an important factor that can increase a range of citizenship opportunities, unfortunately, many students still struggle with mathematics learning. It is imperative, therefore, that we understand what effective mathematics teaching looks like.

The New Zealand Ministry of Education's Iterative Best Evidence Synthesis [26] suggests that effective mathematics teaching must be:

- Grounded in the general premise that all students have the right to access education and the specific premise that all have the right to access mathematical culture;

- Focused on optimizing a range of desirable academic outcomes that include conceptual understanding, procedural fluency, strategic competence, and adaptive reasoning;

- Acknowledged that all students, irrespective of age, can develop positive mathematical identities and become powerful mathematical learners;

- Based on interpersonal respect and sensitivity and be responsive to the multiplicity of cultural heritages, thinking processes, and realities typically found in our classrooms; and

- Committed to enhancing a range of social outcomes within the mathematics classroom that will contribute to the holistic development of students for productive citizenship.

Moreover, according to [26], mathematics teachers play a strategic role in developing effective teaching and learning. As facilitators for their students, they are the key factor in developing effective teaching whilst, simultaneously, creating opportunities for effective learning. Past research has indicated that there are a number of aspects which are important to effective teachers, such as, building intimate relationships with students, developing capability and self-confidence, facilitating students' intellectual demands and providing opportunities for students to learn productively [27]. Students need teachers who are friendly, enthusiastic, caring and helpful; they want teachers who build relationships and inspire them to work hard and achieve success [27][28]. During the teaching process, a good relationship between a teacher and his or her students is considered to be important. Therefore, for improving students' chances for academic success, teachers should strive to create positive personal relationships with students.

It is generally agreed that there is a strong relationship between the quality of teaching and student attainment [29][30]. As such, mathematics 
teachers should optimize their role in mathematics teaching to optimize students' mathematics learning outcomes by using their knowledge, skills, resources and incentives to provide students with the best of learning opportunities to achieve the best of learning outcomes. [5] suggest that an effective teacher should ensure that all students are given the opportunity to think and work by themselves, in which they are not required to process the varied, sometimes conflicting perspectives of others.

Further, effective mathematics teaching, according to [2], depends, to a large extent, on the expertise of teachers; consequently, their knowledge of the subject - of mathematical principles and processes - and their professional training are crucial. Therefore, it is important that mathematics teachers constantly monitor, adapt and improve the effectiveness of their mathematics teaching. As teaching is a dynamic activity, the teacher, as learning facilitator, needs to frequently evaluate the effectiveness of their teaching. Further, the result of their evaluation should be used to improve the quality of their teaching

In addition, to be effective, mathematics teaching should be intellectually relevant to students' needs. Therefore, applying appropriate intellectual demands on students and increasing students' involvement in their learning are crucial because these would influence their learning outcomes. [31] suggests that high quality outcomes for students requires more than teachers simply changing their practices. In other words, to improve the quality of outcomes teachers need to improve the quality of their instructions, and improving the quality of the instructions should include considering the students' needs, based on their backgrounds.

Furthermore, to increase the effectiveness of mathematics teaching, teachers need to take into consideration the students' life experiences so that they can provide mathematics activities that are meaningful to students' daily activities. In other words, mathematics teaching should be intellectually relevant to students' world [32]. Given this, mathematics teachers should not only teach students 'what mathematics is' or the mathematics content in the curriculum, but should also show students, explicitly, how mathematics is applicable to their daily activities. [33] state that in learning mathematics students should frequently undertake activities that make connections between mathematics topics and can be applied to real-life situations. These involve showing the applicability of mathematics and increasing students' involvement in their learning. Further, [33] suggested that students need to be given high quality tasks that require them to engage with the processes which are promoted, such as, problem solving; drawing out connections between mathematics topics; communicating in written form; justifying and providing evidence for their answers; and acquiring a deeper understanding of mathematics and how it can be applied. This finding implies that learning associated with high quality tasks, enables students to demonstrate their high level intellectual outcomes.

Given that the research investigated whether reform of mathematics education using the Productive Pedagogies framework, Connectedness dimension in particular, might be useful, the next section describes the framework and provides an overview of research related to the effectiveness of the framework.

\section{Productive Pedagogies Framework}

The importance of mathematics within society and the current disconnection of mathematics education with the lives of students has resulted in a mathematics education movement that is concerned both with providing equitable access for all students to learn effectively and in helping students to be protagonists, with respect to changing their world in ways that are more socially just [34]. This movement is concerned with the intellectual demand placed on students within the classroom, the relevance of the mathematics taught to their lives outside of school, the level of support provided to students within the learning environment, and the lack of recognition of students' differences. It is anticipated that this movement, with its aim of creating meaningful learning experiences for students, regardless of their background, will result in a significant improvement in the quality and effectiveness of mathematics education. The Productive Pedagogies framework is borne out of this movement and provides a means by which teachers can improve the quality of teaching and learning, in general, and in teaching and learning of mathematics, in particular.

The Productive Pedagogies framework was built upon a large body of research related to the production of socially equitable student learning outcomes [35]. Through its dimensions, the Productive Pedagogies framework provides a list of characteristics that have been found to be related to effective teaching. The framework has been recognized as a means of creating a learning process that has a positive impact on students' academic and social outcomes. The Productive Pedagogies framework involves four overarching dimensions, these being: 1) Intellectual Quality; 2) Connectedness; 3) Supportive Classroom Environment; and 4) Recognition of Difference [31]. Each of these four dimensions includes a number of elements (20 in total). 
The Intellectual Quality dimension is related to a heightened intellectual demand on students and stresses the importance of presenting all students, regardless of their background and perceived academic ability, with intellectually challenging work [36]. There are a number of studies that have shown that students do not achieve their highest academic performance because schools do not always require them to complete work of a high intellectual quality [37]. Therefore, [38] purport that, in terms of intellectual quality in mathematics, the tasks should enable and foster deep mathematical learning. To be effective, this dimension demands that challenging activities be incorporated into the teaching process as a matter of priority for all students, especially for those from disadvantaged groups and low socioeconomic backgrounds.

The Intellectual Quality dimension includes six elements, these being, metalanguage (focusing on aspects of language, grammar and technical vocabulary); substantive conversation (focusing on interaction among students and between teacher and students, about the ideas of a fundamental topic); deep knowledge (focusing on establishing relatively complex connections to those central concepts); deep understanding (focusing on encouraging students to grasp the relatively complex relationships between the central concepts of a topic); higher order thinking (focusing on the transformation of information by combining the information to synthesize, generalize and explain to get conclusions); and knowledge as problematic (focusing on an understanding of knowledge not as a fixed body of information).

The second dimension, Connectedness, is related to connecting learning to students' lives outside of school. This dimension focuses on making classes relevant for students by considering the students' culture and what they already know. The Connectedness dimension designed to accommodate the needs of students, in particular, those who are marginalized or low achieving. This dimension was developed to ensure that students engage with real, practical or hypothetical problems which connect to the world beyond the classroom [39]. It is anticipated that, by incorporating pedagogies that connect classroom learning with the real world will motivate students to engage with the learning process, a link which is often absent when the curriculum is divorced from the lives of students [37]. Further, the notion of Connectedness links new knowledge with the students' background knowledge and the world outside of the classroom. As such, this dimension requires teachers to identify and solve intellectual and/or real problems.

The elements related to the Connectedness dimension are: knowledge integration (focusing on connecting two or more sets of subject area knowledge); background knowledge (focusing on connecting between students' background knowledge and experience and the topics, skills and competencies); connectedness to the world (focusing on connecting the lesson and learning activities to competencies or concerns beyond the classroom); and problem-based curriculum (focusing on presenting specific practical, real problems or sets of problems to solve by students).

The third dimension, Supportive Classroom Environment, aims to support the two dimensions introduced previously (Intellectual Quality and Connectedness). This dimension focuses on providing an environment that facilitates intellectual stimulation by developing positive and mutually-supportive relationships within the learning environment. Such relationships break down the power imbalance between teachers and students and are important given that many students are resistant to being overpowered and controlled [40][41]. Past research in the field of learning environments provides strong and convincing evidence that the quality of the learning environment is strongly and consistently related to a range of student outcomes [42]. The elements related to the Supportive Classroom Environment dimension, include: student direction (focusing on providing student opportunities to involve in determining specific learning activities or outcomes); social support (focusing on a learning atmosphere of mutual respect and support between teacher and students and among students); academic engagement (focusing on encouraging students to engage and on-task during the lesson in order to demonstrate academic engagement); explicit quality performance criteria (focusing on explicitly judging the range of student performance at different stages); and self-regulation (focusing on considering the direction of student behavior implicit and self-regulatory).

The fourth dimension, Recognition of Difference, focuses on the need for inclusive classroom practices that both support and incorporate the diversity of students' backgrounds, experiences and abilities [43]. The Recognition of Difference dimension is strongly related to issues of social justice and inclusion [44]. It was with this in mind that, for the purpose of the present study, this dimension was extended to include a focus on social justice. The presence of this dimension develops student awareness of how various factors, such as, gender, age and socioeconomic status affect their identities [45]. A focus on this dimension serves to encourage students to expose their understandings and to develop their ability to construct a perception of non-domination or democratic concepts. That is, by providing opportunities for students to actively learn how to become democratic 
individuals, they are likely to develop an understanding that all students have the right to be treated fairly. Recognition of difference dimension was developed to encourage students to understand their identity as members of a society.

The Recognition of Difference dimension embraces five elements, these being: cultural knowledge (focusing on cultural identity in which there is explicit appreciation of the characteristics); inclusivity (focusing on actively engaging all students from diverse backgrounds);narrative (focusing on the style of teaching that consists of a linked sequence of events and involves an emphasis); group identity (focusing on building a sense of community and identity of students); and active citizenship (focusing on encouraging active citizenship within the classroom).

Given that the Productive Pedagogies framework provides a reasonably comprehensive account and guidelines for effective teaching practice, it was anticipated that such a framework could, potentially, support the development of effective mathematics teaching in Indonesia. The Productive Pedagogies framework does not, however, provide a ready-made technique for teaching but, rather, an approach to creating a place, space and vocabulary for teachers to use in classroom instruction discourse [46]. Therefore, in its implementation in the classroom, teachers are required to adapt the dimensions of the framework to be more in line with the 'local' situation.

There is a challenge is that many teachers, particularly in Indonesia, rely on transmission approaches of teaching, largely as a result of their own previous learning experiences. This problem is not unique to Indonesia. According to Simon (2008), teachers in many countries that are currently embracing movements to reform the teaching of mathematics, were educated under the traditional system of mathematics instruction. Teacher education should help teachers to understand the theoretically grounded view of learning that shifts traditional conceptions of knowledge as being developed by those who are involved in the teaching and learning process [47].

As discussed in the previous section, it is becoming more widely recognized that reflection is a means through which the gap between theory and practice can be bridged [48][49][50]. Through a series of action research cycles, that involved the use of reflection at each stage, this study examined the effectiveness of the Productive Pedagogies framework, which was Connectedness dimension, to bring about change in the classroom in terms of improved interactions and meaningfulness.

Overall, the findings suggested that, although there were differences in the extent to which the capacity of the teachers was built over the three action research cycles, all three teachers made improvements. That is, the success of the implementation of the individual elements, within the Productive Pedagogies framework, improved for all teachers in the Connectedness dimension. The findings generally support that the use of the elements of the framework, Connectedness dimension in particular, enabled the teachers to develop constructive practice which was shown through improved interactions and connectedness of the topics learned by the students.

As a result of the implementation of the dimension of Connectedness of the Productive Pedagogies framework, the students became more willing to respond to the teachers' questions and to express their ideas. Students began to raise their hands more often to answer their teachers' questions or to comment on what their peers said. The teachers encouraged this further by consciously selecting a range of students so that, regardless of that competence, background or gender, all students were given the changes to respond.

The interactions between students also became more frequent, on-task and positive. The use of cooperative learning groups, coupled with a more supportive learning environment, led to improved interactions. These interactions are important, according to [51], who argued that teachers' response to the needs of students tends to make students have a sense of inclusion, honor and also have a sense of human dignity. These changes also were in line with the social constructivist perception of students, which is based on the beliefs that teaching and learning should provide students with both the skills that enable them to be part of their society and the information that they need [52]. Further, these improved interactions encouraged the students to construct their knowledge which, according to [53], is influenced by the active individual development of the learners and the social and cultural interactions in mathematics practices.

The implementation of the Productive Pedagogies framework, Connectedness dimension, also saw an improvement in the degree to which the teachers made mathematics relevant to the everyday lives of their students. All three of the teachers increased the connectedness of mathematics in the classroom. They all made a point of connecting new learning to the students' prior knowledge and encouraged the students to connect the concepts within the lessons to other relevant concepts that they had learned in previous topics, thereby deepening the students' understanding of the mathematics concepts.

The teachers also tried to connect the lesson activities to the lives of their students. That is, they started to use examples that were relevant to the 
students and ensure that activities and projects were meaningful. The three teachers also attempted to involve students' ideas to support the learning process (something that they never did prior to the introduction of the Productive Pedagogies framework). In addition, the teachers made attempts to use illustrations and concrete examples in their lessons to make the abstract concepts easier to grasp. Additionally, the teachers were more likely to engage students in meaningful and relevant activities. Not only were the activities more relevant to the students' everyday life (as discussed earlier) but the teachers also gave students' opportunities to select the activities that they would like to do, further enhancing the engagement of the students.

[54], in their investigation of the factors in mathematics classrooms that either hinder or support students' engagement, found that minority students fail to engage in high-level mathematical tasks due to a lack of opportunities to participate in challenging mathematics learning experiences rather than to a lack of potential. Based on their research findings they recommended that teachers provide meaningful mathematics for their students. By providing a more meaningful teaching approach, the teachers, thus, engaged in a more socially just pedagogy.

The connectedness dimension relates new knowledge with students' background knowledge and to their life outside of the classroom through identifying and solving real life problems [55]. By providing students with opportunities to engage in activities in which they can see the connection between what they are learning with their previous experiences and acquired knowledge they are better able to interpret the lessons and to build new concepts. There is widespread agreement that previous experiences and prior knowledge influence the learning process, and that learners construct new concepts based on previous experiences and prior knowledge. In turn, both of these indirectly affect the learning outcomes. Neglecting previous experiences and prior knowledge can result in the students learning something different to the teacher's intentions.

To assist students in their construction of new schemas, teachers need to consider students' prior knowledge and learning experiences when planning and implementing lessons. These experiences and prior knowledge exist not only at the level of concepts, but also at the levels of perception, focus of attention, procedural skills and beliefs about knowledge. In addition, teachers need to consider providing students with opportunities to engage in activities that are connected with real world situations and with problems that are likely enhance students' understanding of their world both in and out of the classroom. [39] believe that, if the work given to students is connected to their worlds, then this will stimulate intellectual activity that is likely to lead to higher intellectual outcomes. Similarly, [37] argue that pedagogies that connect the classroom with reality enable and motivate students to engage in the learning process. [56] purports that, linking mathematics learning to real world situations, can improve students' understanding of mathematical concepts.

\section{REFERENCES}

[1] Sullivan, P.. Teaching mathematics: Using research-informed strategies. Victoria: Australian Council for Educational Research, 2011.

[2] Parveva, T., Noorani, S., Ranguelov, S., Motiejunaite, A., \& Kerpanova, V. Mathematics education in Europe: Common challenges and national policies. Brussels: Eurydice, 2011..

[3] Fuata'i, K. A.. Educationally disadvantaged students' mathematics competence and reflections. Armidale, Australia: University of New England. Retrieved 30 April, 2013, from http://publications.aare.edu.au/09pap/afa091282.pdf 2010.

[4] Schmidt, K. D. Mathematics for a broken, beautiful world: A modular resource package for late secondary and early postsecondary math educators. (An Independent Learning Project). Unpublished, 2011.

[5] Anthony, G. \& Walshaw, M. Effective pedagogy in mathematics: Best Evidence Synthesis Iteration [BES]. Wellington, New Zealand: Ministry of Education, 2007.

[6] Hightower, Delgado, Lloyd, Wittenstein, Sellaers \& Swanson, Hightower, A. M., Delgado, R. C., Lloyd, S. C., Wittenstein, R., Sellers, K., Swanson, C. B.. Improving student learning by supporting quality teaching: Key issues, effective strategies. Bethesda, US: Editorial Projects in Education. Retrieved 18 September, 2011, from: www.edweek.org.

[7] Hadi, S. Effective teacher professional development for the implementation of realistic mathematics education in Indonesia. Enschede: Doctoral dissertation, University of Twente, 2002.

[8] Armanto, D.. Teaching multiplication and division realistically in Indonesian primary schools: A prototype of local instructional theory. Enschede: Print Partners, 2002

[9] Dahlan, J. A.. Improving reasoning ability and mathematical understanding junior high school students through open-ended learning approach.Unpublished dissertation, Sekolah Pasca Sarjana Universitas Pendidikan Indonesia (SPS UPI), Bandung, Indonesia, 2004.

[10] Sembiring, R. K., Hadi, A. S., \& Dolk, A. M. (Reforming mathematics learning in Indonesian classrooms through RME.ZDM Mathematics Education. 40, 927-939 2008.

[11] Zamroni. Paradigma pendidikan masa depan. Yogyakarta, Indonesia: Bigraf Publishing 2000.

[12] Van Beveren. A model of knowledge acquisition that refocuses knowledge management. Journal of Knowledge Management, 6(1), 18-22, 2002.

[13] Shakoor, A. \& Azeem, M..A conceptual framework of acquisition of mathematical knowledge to teach algebra. British Journal of Humanities and Social Sciences, 2(1), 154-168 2011

[14] Zazkis, R. \& Leikin, R. Advanced mathematical knowledge: How is it used in teaching? Proceedings of Congress of the European Society for Research in Mathematics Education (CERME), Lyon France.Retrieved 18 March, 2012, from www.inrp.fr/editions/cerme6, 2009.

[15] Azra, A.. Paradigma Baru Pendidikan Nasional: Rekonstruksi dan Demokrasi. Jakarta: Kompas2002 
[16] Zulfikar, T. The making of Indonesian education: An overview on empowering Indonesian teachers. Journal of Indonesian Social Sciences and Humanities, 2, 13-39, 2009.

[17] Hoban, G. F.. Theories and models of professional development. In R. J. King, D. M. Hill \& J. A. Retallick (Eds.), Exploring professional development in education (pp. 134155). Riverwood, NSW: Social Science Press, 1997.

[18] Von Glasersfeld, E. A constructivist approach to teaching.In L.P. Steffe\& J. Gale (Eds.), Constructivism in education (pp.315). Hillsdale, N.J: Laurence Erlbaum 1995.

[19] Fung, C. The efficacy of a constr,uctivist approach to the training of Chinese mathematics teachers. Unpublished Master Thesis, Curtin University of Technology, Perth. 2002.

[20] Simon, M.The challenge of mathematics teacher education in an era of mathematics education reform. In B. Jaworski \& $\mathrm{T}$. Wood (eds.), The international handbook of mathematics teacher education: The mathematics teacher educators as developing professional (17-30). Netherlands: Sense Publishers, 2008.

[21] Sutton, R. E., Cafarelli, A., Lund, R., Schurdell, D., Bichsel, S. A developmental constructivist approach to pre-service teachers' ways of knowing.Teaching \& Teacher Education.12(4), 413-427, 1996.

[22] Gunstone, R. Constructivism learning and the teaching of science. In B. Hand \& V. Prain (Eds), Teaching and Learning in Science. The Constructivist Classroom (pp. 3-20). Sydney: Harcourt Brace, 1995.

[23] Jonassen, D.H. \& Grabowski, B.L. Handbook of individual differences, learning, and instruction. Hillsdale: Lawrence Erlbaum Associates, 1993.

[24] Tytler, R.. Teaching for understanding in science: Constructivist/conceptual change teaching approaches. Australian Science Teachers Journal, 48(4), 30-35, 2002.

[25] O'Toole, J. Building powerful understanding by connecting informal and formal knowledge. In P. Grootenboer, R. Zevenbergen \& M. Chinnappan (Eds.), Identities, cultures and learning spaces: Proceedings of the 29th Annual Conference of the Mathematics Education Research Group of Australasia held in Adelaide, 2006 (pp. 384-391).Retrieved 4 September, 2012, from http://www.merga.net.au/documents/RP432006.pdf.

[26] Anthony, G., \& Walshaw, M. Effective pedagogy in mathematics. Educational Practices, 19, 1-30, 2009

[27] Slade, M..What makes a good teacher? The views of boys. Paper presented at the "Challenging Futures? Changing Agendas in Teacher Education" Conference, Armidale: University of New England, 2002.

[28] Rowe, K.. The importance of teacher quality as a key determinant of students' experiences and outcomes of schooling. Keynote address presented at the Australian Council for Educational Research (ACER) conference, Melbourne, Australia, 2003

[29] Darling-Hammond, L.. Does teacher preparation matter? Evidence about teacher certification, Teach for America, and teacher effectiveness. Education Policy Analysis Archives, 2005, 13(42), 16-20.

[30] Aaronson, D., Barrow, L. \& Sander, W., Teachers and student achievement in the Chicago public high schools. Journal of Labor Economics, 2007, 25(1), 95-136.

[31] Mills, M., Goos, M., Keddie, A., Honan, E., Pendergast, D., Gilbert, R., Nichols, K., Renshaw, P., \& Wright, T. Productive pedagogies: A redefined methodology for analysing quality teacher practice. The Australian Educational Researcher,2009, 36(3), 67-87.

[32] Davis, P. J., \& Hersh, R. The mathematical experience. Boston: Houghton, Mifflin, 1981.

[33] Jeffes, J., Jones, E., Wilson, M., Lamont, E., Straw, S., Wheater, R., \& Dawson, A. Research into the impact of project maths on student achievement, learning and motivation: Final Report. Slough: National Foundation for Education Research, 2013.
[34] Ball, D. L.. Improving mathematics learning: Where are we and where do we need to head. Paper presented at the annual meeting of the Carnegie Corporation of New York/Institute for Advanced Study Commission on Mathematics and Science Education, New York, NY, 2008

[35] Ladwig, J. G., Luke, A. \& Lingard, R. Redefining school reform: The social-theoretical rationale of the Queensland School Reform Longitudinal Study. St. Lucia: University of Queensland Graduate School of Education, 1999.

[36] Sizer, T..Horaces' Hope. Boston: Houghton Mifflin, 1996.

[37] Hayes, D., Mills, M., Christie, H. \& Lingard, B. Teachers and schooling making a difference: Productive pedagogies, assessment and performance. Sydney, NSW: Allen \& Unwin, 2006.

[38] Zevenbergen, R., \& Niesche, R. Reforming mathematics classrooms: A case of remote Indigenous education. Brisbane: Griffith Institute for Education Research.Zevenbergenand Niesche, 2008

[39] Education Queensland. Queensland School Reform Longitudinal Study. Brisbane: Queensland Government 2001.

[40] Mills, M. Toward a disruptive pedagogy: Creating spaces for student and teacher resistance to social injustice. International Studies in Sociology of Education, 1997, 7(1), 35-55.

[41] Martino, W., \& Pallotta-Chiarolli, M..So what's a boy? Addressing issues of masculinity and schooling. Maidenhead: Open University Press, 2003.

[42] Fraser, B. J.. Classroom learning environments: Retrospect, context and prospect. In B. J. Fraser, K. G. Tobin and C. J. McRobbie (Eds.), Second International Handbook of Science Education (pp. 1191-1239). New York: Springer, 2012

[43] Queensland School Reform Longitudinal Study (QSRLS). School Reform Longitudinal Study: Report, March 1999. St. Lucia: University of Queensland Graduate School of Education, 1999.

[44] Lingard, B., \& Mills. M.. Pedagogies making a difference: Issues of social justice and inclusion. International Journal of Inclusive Education, 2007, 11(3), 233-244.

[45] Gutstein.E. Teaching and learning mathematics for social justice in an urban, Latino school.Journal for Research in Mathematics Education, 2003, 34(1), 37-73.

[46] Atweh, B., \& Brady, K.. Socially response-able mathematics education: Implication of an ethical approach. Eurasia Journal of Mathematics, Science \& Technology Education, 2009, 5(3), 267-276.

[47] Tatto, M. T. Improving teacher education in rural Mexico: The challenges and tensions of constructivist reform. Teaching and Teacher Education, 1999, 15(1), 15-35.

[48] Jaworski, B.. Mathematics teacher research: Process, practice and the development of teaching. Journal of Mathematics Teacher Education, 1998, 1, 3-31.

[49] Jaworski, B. \& Gellert, U.. Educating new mathematics teachers: Integrating theory and practice, and the roles of practising teachers. In A. Bishop, M. Clements, C. Keitel, J. Kilpatrick, \& F. Leung (Eds.), Second international handbook of mathematics education (pp. 829-875). Dordrecht, the Netherlands: Kluwer Academic Publishers, 2003.

[50] Malara, N., \& Zan, R. The problematic relationship between theory and practice. In L. D. English (Ed.), Handbook of international research in mathematics education (pp. 553-580). New Jersey: Lawrence Erlbaum Association, Inc., Publishers, 2002.

[51] Gay, G. Culturally responsive teaching: Theory, research, \& practice. New York, NY: Teachers College Press, 2000.

[52] Henniger, M. L.. The teaching experience: An introduction to reflective practice. Upper Saddle River, NJ: Pearson Education, 2004.

[53] Cobb, P Where is the mind? Constructivist and sociocultural perspectives on mathematical development.Educational Researcher, 1998, 23(7), 13-20. 
[54] Henningsen and Stein. Mathematical tasks and student cognition: classroom-based factors that support and inhibit high-level mathematical thinking and reasoning. Journal for research in mathematics education, 1997, 524-549.

[55] Education Queensland.. A guide to productive pedagogies classroom: Reflection manual. Brisbane: Department of Education, 2002.

[56] De Lange, J.. Using and applying mathematics in education. In A. J. Bishop et al. (Eds.), International handbook of mathematics education, (pp. 49-97). The Netherlands: Kluwer Academic Publishers, 1996. 